\title{
Taoism Traditions in the Artistic Culture of China
}

\author{
Aleksandr A. Alepko* \\ Khabarovsk State Institute of Culture \\ 112 Krasnorechenskaia Str., Khabarovsk, 680045, Russia
}

Received 20.11.2015, received in revised form 18.02.2016, accepted 14.04.2016

\begin{abstract}
In this article the author examines the influence of Taoism on the artistic culture of China, in particular, on the national art. The subject of the research is the interpretation of images of Chinese painting by the Taoist cultural tradition.

The study confirmed that in accordance with the Taoist tradition, the Chinese artist looked at life from the perspective of art, never painted from nature and never made sketches, while it is conventional in European painting. Before painting pictures, the Chinese artist, like a naturalist, carefully and painstakingly studied nature in all its smallest forms.

In their works, Chinese artists were always guided by the idea of the dynamic unity of opposites that complemented each other and, thus, needed each other. The artist was not a classicist or a romantic, he was both. The paintings were neither naturalistic nor idealistic, they combined these qualities. The style of Chinese artists involved a combination of the general and the individual. This was the way due to which Chinese artists found "the inner reality" in their paintings.
\end{abstract}

Keywords: Taoism, painting, character, artist, landscape, calligraphy.

DOI: 10.17516/1997-1370-2016-9-6-1264-1276.

Research area: culture studies.

The relevance of the presented work is caused by a number of sociocultural and general scientific circumstances. This article meetstoday's requirements due to expanding cultural contacts between China and Russia, the growing interest in the deep roots of the cultures of both countries and poor knowledge of their mutual influence. At the same time, Taoism, as one of the components of the traditional cultural heritage, is a complex component of the spiritual culture of modern China. Reflecting the ethnocultural features, it becomes a powerful direct and indirect factor of the impact on ideology, politics and culture of modern China.
The philosophy of Taoism became an active force on the world stage in the $\mathrm{XX}$ century thanks to the spread of Chinese culture, operating at different levels. It is no coincidence that "TaoTeChing" ranks second in the world afterthe translation of the Bible. According to the French sinologist and researcher K. Schipper,this is conditioned by the fact that Taoism is viable thanks to the exceptional succession and continuity of tradition (Schipper K., 1982).

The importance and relevance of the research in Taoism is explained by the fact that in the conditions of the dynamic development of the intercivilizational contacts between China

(C) Siberian Federal University. All rights reserved

* Corresponding author E-mail address: alexander.alepko@yandex.ru 
and Russia,it is necessary to assess the dynamics of the development of Chinese cultureadequately and understand the features of the Chinese worldview.

Working on this article,the author used various sources of literature, from which he derived the necessary information to study the topic. Among the Russian-language sources, first of all,it is necessary to note the fundamental works of M.E.Kravtsova "The History of Chinese Art" and "The History of Chinese Culture", published in St. Petersburg (Kravtsova M.E., 2004; Kravtsova M.E., 1999), where the author consistently highlights various aspects and the history of the development of traditional Chinese art, and particularly painting.

The translations of classical texts on the art of Chinese philosophers and artists, as well as the scientific comments on them in the books "Talks about Painting by Shitao",'The East in the West”by E.V. Zavadzkaia(Zavadskaia E.V., 1978; Zavadskaia E.V., 1970), "Chinese Art" byV.V. Maliavin(MaliavinV.V., 2004) were valuable for this article.

The philosophical-aesthetic problems of Chinese painting reflected in the following theoretical writings:"Cults, Religions, Traditions in China"byL.S. Vasil'eva; "Aesthetic Problems of the Old Chinese Painting"by E.V. Zavadzkaia; "Taoism Aesthetics" by V.A.Krivtsov; "Chinese Civilization"by V.V. Maliavin; "The Principles of Chinese Painting" by G. Rowley,and others (Vasil'ev L.S., 1970; Zavadskaia E.V., 1993; Krivtsov V.A., 1993; Maliavin V.V., 2001; Rowley G., 2004).

The subject of the article's research is the interpretation of the images of Chinese painting of the Taoist cultural tradition.

The author of the article applieda complex of the methods of art, culturological, philosophicalaesthetic research, including the methods of comparative-historical and compositional-artistic analysis of the works of Chinese art. The scheme of the author's analysis of the problem includes the subject, endowed with consciousness and will, and the opposing object of nature, independent on the mind and will of the subject, and related only to the cognitive attitude in keeping with the Taoist tradition.

Taoism can be called a true focal point of Chinese culturewithout exaggeration. It provided continuity between the elite wisdom of Tao and the beliefs of the common people, the principles of internal improvement and all the way of lifeofChinese people. For the Taoists, their religion was only something like "a useful illusion", because the images of the gods, like the rest of the visible world, were, in their view, only the "reflections" of hidden Tao. The Taoist philosophy of nature offers an insight into the world as a change of energies or "elements", which include five ones, namely "Tree", "Fire", "Earth", "Metal" and "Water." Each of these elements is a certain quality of life. At the same time, the world of Tao is the depth of mutual reflections, "wonderful meetings" of disparate powers, and the principle of its existence is expressed in the form of "Heavenly Scales" equalizing incomparable things. The reality for the Taoist adept isChaos (hun-tun in Taoism) as orders without number, the infinite wealth of diversity (Tao TeChing. Religions of China.Chrestomathy, 2001; Tkachenko G.A, 2008).

The concept of "balancing things" (qi wu) was of a great importance for Taoist philosophy, according to which the world is a kind of absolute unity (ChinesePhilosophy. Encyclopedia, 1994). There is no place for clear boundaries between things in it, all is fused with each other, and all is present in all. There are no absolute valuesin this world, nothing itself is either beautiful or ugly, either large or small, and all exists only in relation to something else, and in close internal communication and interdependence (Parable 
of Death. Tao Te Ching.Religions of China. Chrestomathy,2001).

Hence it is clear that the world of Taoism is an illusory world, forever elusive, symbolic, but precisely because of this it mediates a fullness of truth.

The Taoist knowledge flattens nature itself, diffusing it to absolute nothingness, to the "vague, nebulous" and "vaguely indeterminate", to the solid darkness, and at the same time to "blinding radiance".(Tao Te Ching.Religions of China.Chrestomathy, 2001)."Being of the truth", something certain, the only truth in the life of culture would seem to be about to tread in this symbolic perspective. But noway.Every time the final and the absolute happen to be not only unspoken, but even not scheduled, and stay somewhere "behind the scenes", behind the word and even the idea (Sun Cho.Yu Tan TaishanFu. Religions of China.Chrestomathy, 2001).

Taoism emphasizes coming closer to nature, uniting with it in a single, total entity. Tao can rightly be called the quintessence of the philosophy oftraditional China. Tao is like the original supreme universality, as the great law of nature and the root cause of all things, as the supreme absolute reality, out of a gigantic flow of which the phenomenal world is born in order to leave there too in the end, and then to reappear updated (Guan Yin Zi. Religions of China. Chrestomathy, 2001; Tkachenko G.A., 2008).

Just as Christianity and Hellenistic art formed the European art, in China a distinctive doctrine of Taoism created the cultural climate in which Chinese painting developed. Chinese painting is the "disclosure" of Tao through the comprehension of the images of reality. Everything that happens has always been perceived according to the laws of nature, a sense of beauty has been embodied in images, so landscapes occupy a dominant position, and celebrationin verses only complements its beauty: according to the philosophy of Taoism, man is insignificant compared to the root cause of the world that is Tao, embodied in natural phenomena.

The spirit of Taoism in the landscape of the Sung time was only a distant echo of the Taoist fantasy of Han bas-reliefes (Gordienko A.N., Kudelev P.E., Perzashkevich O.V., 2008; Maliavin V.V., 2000). Later the artists refused obvious allegories and frequentpainting of the immortal; nature appears in their works increasingly transformed and spiritualized.

In China people have long been talking about the proximity of painting and calligraphy. The hieroglyphic symbol "yihua" (one line,literally) certifies the organic unity of painting and calligraphy. Painters and calligraphers use the same materials and tools (brush, paper and ink) and the same linear way of writing. There is so much in common between Chinese calligraphy and painting that they are even considered to be closely related. Developing in stylistic unity, they are linked and move each other forward. This suggests that Chinese fine art is based on a line (Gordienko A.N., Kudelev P.E., Perzashkevich O.V., 2008; Maliavin V.V., 2000). Chinese painters created works of high artistic excellencewith thesimplest lines.

The line in Chinese canvases not only connects and separates, but also brings out planes, measures the space and time and gathers them together. At the same time, it is just a symbol of the space-time continuum, the trail of the continuity of the awakened spirit. In Chinese landscapes lines are often converted into points, which are designed to indicate significant interruptions in the duration of consciousness and the imperturbable peace of mind.

A curve as a sign of the cycle of the Great path had a special significance in Chinese art graphics. In particular, the curvature of trunks and branches of trees, which is so eye-catching for Chinese artists, was a strong indication of the 
life forcein their eyes. It is no coincidence that Chinese folklore attributedmagical propertiesto circle, node, all sorts of ornaments, and curls of the "cloud pattern" inparticular.

The spiral lines of traditional Chinese graphics mean the time of so-called"coagulation", "zhe de" (going into depth, literally). According to the Chinese tradition in the phase of "coagulation" every progressive movement is converted into a return, circularmovement,and "an everlasting winding thread of the path" (by Lao $\mathrm{Zi}$ ) is not cut off. The time of "coagulation" also marks the transformation of planar and surface images into the images of the depth and the inner form (Maliavin V.V., 2000).

The artists of traditional China liked to repeat, that painting is only "one line". The composition of the Chinese classical landscape reproduced the structure of the hieroglyphic sign. It was dominated by asymmetry, which universally permitted a changeable unobtrusive order. According to the experts in Chinese painting, itrelated to the so-called universal "consonance of trends", namely the harmony of yin and yang. In fact, the Chinese landscape "Shan Shui" (mountains-waters, literally) is a combination of the upward light and the downward dark, which arethe Heaven and the Earth. The first part of the canonical book "Tao Te Ching" states that "presence and absence produce each other", "the complex and the simple create each other", "the long and the short check each other" and "the high and the low turn to each other" (Maslov A.A., 2005).

The oppositions of "empty" and "filled", "light" and "heavy", "thick" and "discharged" in certain fragments of the classical Chinese landscape are the same. The mobility of structural oppositions of the picture meant that at any given time its semantic parts could not be equal, that one of them is certainly dominant, while the other is subordinate. That is wherea traditional principle of separation of the two characters, namely "the host" and "guests" in Chinese fine arts, comes from.In the landscapes the role of "the host" usually belongs to the mountain, and the role of "guests" is given to streams, trees and people (Maliavin V.V., 2000).

The language of "one line" of being is universal, but at the same time is not uniform. It is the language of creative metamorphosis. Every detail in the traditional Chinese landscape is painted with certainty, assuming a thoughtful and patient study of its properties. All the images in the picture are spiritualized with the creative power of life and transgress their own boundaries. Displacement, eccentricity, boundary become the norm and the law of existencein the picture. In the work the continued evasiveness ofthe course of nature beyond its limits not only demonstrates the reality surpassing its own manifestation, but theprinciple of manifestation itself as well. Hence, the decorative effect, being the sign of the form's limit and the symbol of the infinite, becomes the defining feature of the image.

Chinese painting is characterized by multi-point and diffused vista, concise and clear composition of the local color spots with expressive and rhythmic contours, as well as the planar painting without cut-off modeling. The Chinese artist can reproduce the riveron a long and narrow paper or silk scroll, creating a feeling of infinity of riverspaciousness, seen from above or from the side, as well as many landscapes, seemingly hidden with a skylinefrom viewers. This can not be achieved by a focus perspective. A cross-cutting perspective of Chinese painting allows the artist to give full play to their imagination and create the artistic world, without bindingthemselves by the scope of thespace limited with the skyline.

The realistic start of a direct observation of reality in Chinese painting is combined with a number of conventional canons. Its majestic 
simplicity and noble rigor do not exclude the subtleties of decorative details.

The images of Chinese painting often embody deep philosophical ideas. The founder of the theory of painting $\mathrm{Se} \mathrm{He}$ in his "Notes on the Categories of Old Painting" (490) formulated six basic principles that artistsshould follow. And the first of them was the requirement to convey "the harmony of energies in a living movement"in the painting, which is inherent in all in nature, to convey its essence, but not the external naturalistic image (Maliavin V.V., 2000).

The images of Chinese painting were given the symbolic value associated with the ideas of ancient cosmogony. The structure of the picturesque scrollwas determined by the most important starts, which are the Heaven and the Earth, between which the main actions, which determine the internal dynamics of the picture,take place. The treatises on the art of composition taught the artist: "Before placing the brush, be sure to determine the place of the Heaven and the Earth ... Between them arrange the landscapecarefully". The dualistic structure of the world, approved in antiquity, appeared as the two opposite principles of the universe, visibly embodied in the Heaven and the Earth, namely male power-yang and female power - yin (Maliavin V.V., 2000). The interaction of these powers gave rise to the five elements, namely water, fire, wood, metal and earth, through which all real, all that exists, was formed.

The annual cycle embodied the circle of birth and death of all things. "The Four Seasons" is a favorite motif of Chinese artists. The culmination of this cycle was the winter solstice, when the power of Yang experienced the most stress, when the mystery of the merger of the Heaven and the Earth took place, when the lightsprangin the depths of the darkness. The notation of the white colour symbolized the emptiness of Tao and the purity of his comprehension-intuition. Therefore, the winter, snowy landscape was considered the best form to express the essence of being (Kravtsova M.E., 1999).

Nature was seen as a place of escape from the oppression of society, as a shelter, where a solitary hermit, poet and philosopher, enjoys its beauty. Considering the landscape, a connoisseur and fancier of painting "got lost in travel" in open spaces. The artist tried to convey the lyrical experience, the mood that arises from contact with nature. He called for a merger with it, to comprehend its secrets.

One feature in the paintings strikes. For example, against the backdrop of the majestic mountains the figures of people are extremely small. This disparity emerged from the Taoist philosophy of artists. According to it, a person is insignificant in comparison with the root cause of the world of Tao, embodied in the majestic natural phenomena. The miniature human figures, depicted in the background of the grandiose landscapes, were to cause thethoughts about the greatness of the universe, in which man is a minor element, subject to its mighty powers. This was the difference of the Chinese culture'srepresentations from the European ones, where manwas paid a key attention and was portrayed as a powerful creative force that transforms the world.

The Chinese artist depicts nature in two ways. The first one, already mentioned, is a landscape of mountains and waters "shanshuihua", that is a type of classical Chinese landscape on long scrolls, where details are not important, while the overall feeling of grandeur and harmony of the world is. The other onethat is not a landscape in the full sense of the word,is a so-called genre of "flowers and birds". It is a kind of the world of animal life which was also extremely common in antiquity and preserved its vitality today. Sometimes the works of this genre were painted on round and album pages, 
on screens and fans and depicted a bird on a branch, a monkey cradling a baby, or a dragonfly, fluttering over a lotus flower. This is where the artist allowed himself to consider every move of a plant or an animal, as if through a magnifying glass, endlessly bringing them closer to the viewer and at the same timeoccasionallyembodying a unified and coherent picture of naturein these little scenes.

The image of mountains and waters is a well-established tradition since ancient times associated with religious-philosophical understanding of nature, where the two powers- active male "yang" and passive female "yin" - interact. In Chinese landscapes mountains were considered the embodiment of man's bright start, the personification of eternal nature. Waters personified the feminine dark principle, the distinctive feature of which is their strength and swiftness of the current, making it the adequate epitome of the space flow - Tao (Kravtsova M.E., 1999). In ancient times, when these ideas were born, mountains and waterswere deified as the rulers of human life. Water brought yields, gave crops or carried terrible floods, it influenced the happiness or misery of people.

Unavailablemountains, shrouded in eternal mystery, were a place where the sungoes. Their peaks touched the sky. This ancient symbolism long lost its original meaningin China, however, was the basis of a strong tradition of depictingnature.

According to the Taoist tradition, the universe arisesfrom the combination of mountains and waters. Mountains are bones of the earth, the water flows areveins, blood, throbbing and bearing life and movement. Artists sought to convey the essence, the world harmony, rhythm, underlying the phenomena of nature. Therefore, they were indifferent to naturalism, the pursuit of external similarity.
In the landscapes of "mountains and waters" nature seemed distant from the viewer, appearing in front of him as something titanic and powerful. Looking at the landscape, man considershimself to be an infinitesimal part of the world. At the same timethe insane courage and the boundless breadth of the expanses unfolded before him make him feel admiration and pride. The very world of Chinese painting is the world of nature, with the life of which man connects with all filaments.

Chinese artists over time developed their ownschool of image ways, which is not like the European school. In the Chinese landscape the farthest object is higher than the previous. Therefore, the Chinese landscape looks more volume, while the European landscape is based on the principles of linear perspective, in other words, the distance of the painting is expressed in the decrease of distant objects relative to the foreground. In the Chinese landscape large objects are placed in the foreground: rocks, trees, sometimes structures. These parts of the foregroundare a kind of large-scale units. Distance is almost not visible, it seems to be smeared, tightened with haze.

There were special essays on how to write a landscape of a mountain, which meaning should be conveyed in a landscape. A true master should be in a quiet monastery in a valley, which is clean and bright like his spirit, because the nature heals the soul. He must be a stranger, but his way of wandering and searching for new places should not happen in the outside world. "Withoutleaving the yard, the sage knows the world, without looking out the window, he sees the natural tao. The further he goes, the less he knows. Therefore, the wise man does not go, but knows" (Tao TeChing, the $48^{\text {th }}$ chapter). Thus, landscape painting is to become a place of pilgrimage of the human spirit, replacing all human thrust to change places and the search for new experiences. The influence of ideas of Taoism can be traced in 
the works of such famous masters of the classical Chinese landscapeas Li Cheng (the X century), Guo Xi (1020-1090), Mi Fu (1052-1109), Ni Zan (1301-1374). (Gordienko A.N., Kudelev P.E., Perzashkevich O.V., 2008; Maliavin V.V., 2000).

The Chinese landscape is not like European. They are distinguished not only by the difference in the form of the picture. In the European landscape, the world depicted by the artist, as if seen by him from the window. It is thepart of nature, the countryside or the city, which the eye of the paintercan cover, and where a person, even if he does not exist in the picture, always feels as if he were the master. The Chinese artist perceives the landscape as part of the vast and spacious world, as the grand space where human personality is nothing, it seems to be dissolved in the contemplation of the great, incomprehensible space absorbing it. The Chinese landscape is always fantastic, despite its reality, as if itsummarized the observations of nature in general.

According to the Russian sinologist V.V. Maliavin, the classical Chinese landscape is a bottomless "pantry of things" (the Taoists' definition of the world), the mirror of the consciousnessthat always stays awake and stores all in itself, where every instant impression suddenly finds its indestructible, everlasting quality. The environment of the landscapeis a match of feelings and meditation, the peace of mind, bestowed by the intimate, modestly unspoken comprehension of the authenticity of things. Its objective world never loses the definition of outlines, as if it was painted on the immensely hollow core background. In fact, the viewers see not the world, but a revelation of the world, the space rediscovered in its particularityas a place and time, as a moment (Maliavin V.V., 2003).

According to the Chinese literary critic of the XIV century Tang Hou,the infinite distance in the picture can be presented only as the abyss of life metamorphosis. In particular, he wrote that "the landscape takes in all the perfection of the creative forces of nature - all the shades of light and dark, clear and rainy, cold and hotweather, dawn and dusk, bright day and dark night. Its types are infinitely variable, and its meaning isinexhaustible" (Bush S., 1971).

The definite content and significance of the Chinese landscape generated its special role in painting, as well as an unusual shape and numerous artistic techniques of itspainting. Many Chinese paintings, which show any part of naturehintingly, are perceived as the landscape, although not belong to this genre. Nature seems to help the artist to give elevation, depth and poetrytohis picture.

It seems Chinese landscapes connect the three worlds: the world of water, the world of stone and the world of tree. They are united by a special pictorial organization of time and space, which is a reflection of the fourth, the most important world. A particular importance was attached to the image of water, which was revered as "the nectar of the gods". According to the legend, the phoenix became a symbol of purity, because it is filled with water. Waterfall is a symbol of the meeting of the Heaven and the Earth. It, like a dragon, expresses the unity of being and nothingness. The world of water also includes clouds or "Celestial Mountains". Rivers, lakes, streams ennoble the Earth with its heaven and absolute beginning.

The world of stone helps us to come downto earth from the clouds, although stones contain a heavenly principle, in particular, in the mountain peaks going to the transcendental heights and belonging to the sphere of the sky and water. Stones were considered "the backbone of the Heaven and the Earth, the abode of the spirits".

The cult of tree is of a particular importance in the artistic culture of China. The willow, which is a modest symbol of beauty and elegance,is 
very oftenpainted. The willow is a sign of spring in nature, and in addition, an attribute of one of the incarnations of the Buddha,that is the goddess of motherhood Guanyin. The tree also symbolizes kindness. Women's grace in it is always compared with the flexibility of a willow.

A pine is especially popular in the Chinese painting.It embodies the Confucian restraint and resistance, and the Taoist ideal of "the useless use" that is bent, gnarled and unfit for handicrafts, and the ancient idea of eternal youth. A pine is a symbol of longevity and permanence, as even in the cold winter, it does not lose its needles. The Taoist "immortals" ate its seeds and resin. This tree with forked needles serves as a symbol of marital happiness, longevity, courage, loyalty, steadfastness in difficult circumstances (Kravtsova M.E., 1999).

A special section of the genre of "Flowers and Birds" is a painting of the so-called "four noble": orchid, winterplum - Meihua, bamboo and chrysanthemum.

An orchid embodies simplicity, purity and hidden generosity. Poets-painters, "pouring out inspiration with the tip of the brush", saw an orchid as a symbol of modesty and a subtle implicit action, enabling to remain free and happy. "When I am glad, I paint orchids. When I am angry, I paint a bamboo", said a Buddhist monk Jue Yin. The subtlety and sensitivity of man was poetically compared with thin leaves of orchids, reacting to the slightest movement of the wind.

"If it is not dawn yet, and the moon, like a jade bead, rolls in the sky, no rough breath will touch the leaves. If the leaves of orchids surge in a strong wind, and flowers are freely and quietly opened, then it is time to rejoice".The flower wascompared with the eyes of a wonderful woman, beautiful not due toher garments, but due to her soul, radiating a divine fragrance.
Chinese people attribute the ability to scare away evil forces and to bring good luck and success in business to an orchid.

A big popularity ofpainting a winter plum is explained by the philosophical content embedded within it, its poetic interpretation and especially ethical symbols. Ameihua symbolizes noble purity, durability and resilience, as "living juices are stored in plum trees even in thesevere frost", while flowers begin to bloom during the snow. Chinese poets-patriots often turned to a meihua symbol to express the ideas of resistance and independence. The painting of a plum was adorable by poets-monks, who putphilosophical constructions of "The Book of Changes" (Yi Jing) in the figurative symbolism of a meihua (Maliavin V.V., 2000).

So plum blossoms symbolized the power of yang (the heaven beginning), and its trunk and branches symbolized the power of yin (the earthbeginning). At the same time the peduncle is Tai $Z i$ (the great limit), whichthe flower after its petals fallreturns to. An opened flower has five petals or five primary movements (wuxing). Stamens represent the 7 planets (five planets, the Sun and the Moon).

The trunk of a plum is portrayed divided into two separate parts, reflecting yin and yang, the branches are located in 4 directions, which embody the 4 seasons. The location and shape of the branches can be of 6 types corresponding to the 6 levels of "The Book of Changes" and the end of the branch has 8 curves-forks corresponding to 8 trigrams (bagua).

There are another nine stages of flower development: ovary, bud, flower with closed petals (young yang), half parted bud, full bloom (mature yang), half fading flower (small yin), which turns into a green fruit of plum while falling (old yin). Therefore, out of the four "noble plants", carrying mainly ethical symbols, ameihuaplum increasingly embodies 
and symbolizes the cosmogonic principles and general laws of nature.

The symbols ofameihuaare concrete. Peduncle is an absolute beginning, a cup that supports the flower. It is drawn by three strokes, as embodies the three forces - Heaven, Earth and Man. The flower itself is the embodiment of the five elements, and therefore it is depicted with five petals. All parts are connected with wood, have an even number of elements which reflects sustainability that is the propertyof theEarth.

A chrysanthemum is beautiful, modest and chaste, the embodiment of the celebration of autumn, wisdom and happiness. This flower is a symbol of the sublime solitude. Unlike spring flowers, which are flexible and charming, a chrysanthemum symbolizes "the late fragrance" or venerable maturity, withdrawal from the world in the sublime solitude ("hermit, pouring the late flavor"). A chrysanthemum is a riot of colors, defying the coming winter. This flower symbolizes the fall, as well as good spirits before the coming bad weather, privacy.

One of the most popular objects of aesthetic realization in paintingis a bamboo, a symbol of vitality, a landmark synonymto a pine. In Chinese paintings a bamboo is not just a plant, but a symbol of human nature. Paintinga bamboo, the artist sang of a true man of high moral character, sometimes comparing him with its own character. The well-known theorist and master of the Chinese landscape of the XI century Guo $\mathrm{Xi}$ wrote that "He who learns to paint a bamboo, takes a bamboo shoot, and when in the moonlight the shadow of the shoot reflects on the wall, a true image of bamboo comes before his eyes" (Maliavin V.V., 2003).

The image of "the three friends of cold winter"(meihua, bamboo and pine trees), along with an orchid, formed "the four perfect", symbolized pure noble people, whose friendship and mutual support had passed all the tests.
The popular Taoist symbols of the artistic culture of China are dragon and phoenix which are symbols of authority, power, and strength. Besides, the dragon is also a symbol of the emperor, China and masculinity; phoenix is the empress and the feminine; lion is a symbol of power and nobility. Tiger symbolizes a protector from evil spirits; crane, turtle and old stones are symbols of longevity; bat and forty are symbols of happy news. Drake and duck, two fish, two butterflies, two lotus flowers on one stalk are symbols of marital happiness; lotus isa symbol of inner purity; pion is a symbol of human beauty, wealth, abundance, honor and splendor; peach is a symbol of longevity and immortality; carp fish is a symbol of wishes for happiness and success; pomegranate is a symbol of wishes for a large male offspring (Kravtsova M.E., 1999).

The images and forms of Chinese painting, its culturological ideas, and often technique were incomprehensible to Europeans. How they could know that the two fluffy mandarin ducks slumbering in coastal reeds or a pair of geeseflying in the sky in the picture of the painter were the symbols of inseparable love, understandable to every educated Chinese person, and the combination of a bamboo, a pine and a wild plum Meihua (the three friends of cold winter), whose image we constantly meet both on Chinese paintings and on vases, mean durability and true friendship.

The allegory and symbolic-figurative interpretation of the world have gotinto the flesh and blood of the Chinese realityfrom time immemorial. A ridge over the lake, a cave in the rocks, a gazebo in the park often got such name as "The Bridge of Orchids", "The Dragon Gate", "A Pavilion for Listening tothe RiverFlow" or "AGazebo for the Contemplation of the Moon," etc. Babies in China are still given poetic names inspired by images of nature, for example, "Swallow", "Shoot", "Meihua" etc. 
Sometimesartistscomplemented theirpicture with the lines of poetry. It is important to mention that sometimes Chinese artists were wonderful poets. The literary critic Zhang Yan Yuan stressed the continuity of poetry with painting and said: "When they could not express their thoughts in painting, they wrote characters, when they could not express their thoughts through writing, they painted pictures" (Maliavin V.V., 2000). So Shi Tao in the picture "Wild Grass", where only the road, overgrown with weeds, is visible, put a label full of a hidden meaning: "This is what grows on the beatenpath" (Zavadskaia E.V., 1978). Under the wild grass contaminating the way, the artist meant conquering Manchus, who came to power in 1644 and detained the traditional way of the development of Chinese culturefor a long time.

Chinese artists not only complemented and emotionally enriched the meaning of their works with poetry, which gave birth to seemingly new images and developed the viewer imagination, but also fit their characters in the picturewith such skill and brilliance that it acquired special completeness and sharpness with that. By itself, calligraphy in the form of inscriptions was frequently placed on the rollsseparately, forming a picture of only characters.

Obviously, the Chinese painting is an amalgamation of fine art and poetic art. In Chinese picturesyou can often find hieroglyphic inscriptions, explaining the meaning and complementing thegistof theshown. So the picture of the artist Ni Zan (the XIV century), which depicts a slim tree with bare branches that grew up on a small island, lost among the vast surface of the water, is first perceived only as a sad landscape. Only after reading the calligraphic inscription placed at the top ofthe picture, we can see that the artist in this lyrical and sad landscape depicted not only nature, but also expressed his bitter feelings caused by the conquest of his country by the Mongols (Kravtsova M.E., 1999).
The language of symbols, devoid of objective reality, is close and understandable only for the true connoisseur of Chinese culture. Only that one can understand it, who understands the meaning of parables. This complex figurative perception of the world, the constant reference to the images of nature to convey their feelings originated in China in antiquity. All Chinese mythology is related to the human struggle against the elements, with the naive and imaginative interpretations of natural phenomena.

The Chinese artist never painted from life and never made sketches, as is customary in European painting. The impression left by many Chinese works is like the artist has just touched the silky feathers of the little bird he painted or spied two butterflies dancing over a flowering tree. This impression is based on the fact that before writing his paintings, the Chinese artist, like a naturalist, studied nature in all its smallest manifestationswith an infinite care. He knew the structure of each sheet and movements of sluggish caterpillars feeding on ripe fruit very well, he knew the soft tread of a stalking tiger and thealert turn of a young deer's head listeningto the rustling of the forest. The painter seemsto let the viewer in on numerous secrets of naturehidden from him.

The blade, on which an insectcrawls, or a goose in the reeds calling his girlfriend are those modest images in the Chinese painting which are never perceivedas a normal humdrum scene. The viewer sees and perceives such compositions as a life of the vast world where each stem is the voicer of the great and eternal laws of existence.

The artist reveals the inner rather than the outer side of life. The Chinese looked at life through the lens of art. All other types of their activities werecolouredwith an artistic attitude. Instead, they followed the fantasies of astrology, alchemy, geomancy and fortunetelling. The Chinese painting has never been 
a servant of religion;it avoided the traps of the mind, whether it is theGreek beauty of the mathematical proportions, or the modern rules of pure abstraction. It avoided the exaltation of the personal identity as it was imprinted in expressionism, romanticism and surrealism. The Chinese painting was distinct inthe perfection of artistic purity.

There where the Western tradition established antagonistic dualities of the spirit and the matter, the human and the divine, the perfect and the natural, the classical and the romantic,the traditional and the progressive, and so on, the Chinese sought to mediation. The Chinese were guided by the idea of the dynamic unity of opposites that complemented each other and thus were in need of each other. The artist should not be either a classicist or a romantic, he should be both. His paintings should be neither naturalistic nor idealistic, they need to combine these qualities. His style is to combine the general and the individual. That was the way Chinese artists searched for "the inner reality" in their painting. From the European point of view, the Chinese sought toconsubstantiatedifferent pairs of polar values.

\section{References}

Bush, S. (1971). The Chinese Literati on Painting: Su Shih (1037-1101) to Tung Ch'ich'ang (15551636). Cambridge, Mass, $227 \mathrm{p}$.

Gaun Yin Zi (2001). Perevodfragmenta [Translation of a Fragment], In Religii Kitaia.Khrestomatia. Sostavlenie E.A. Torchinova [Religions of China. Chrestomathy.Composed by E.A. Torchinova]. St. Petersburg, Evraziia, 103-129.

Gordienko, A.N., Kudelev, P.E., Perzashkevich, O.V. (2008). Kitai.Istoria, kul'tura, iskusstvo. Illustrirovannaiaentsiklopedia. [China.History, Culture, Art.Illustrated Encyclopedia]. Moscow, Eksmo, Nasheslovo, 160 p.

Tao TeChing (2001). Perevodfragmenta [Translation of a Fragment], In ReligiiKitaia.Khrestomatia. Sostavlenie E.A. Torchinova[Religions of China. Chrestomathy.Composed by E.A. Torchinova]. St. Petersburg, Evraziia, 17-25.

Kitaiskaia filosofia. Entsiklopedicheskii slovar'. Glavnyi redactor M.L. Titarenko [Chinese Philosophy. Encyclopedic Dictionary. Head Ed. M.L. Titarenko]. (1994). Moscow, Mysl', 573 p.

Kitaiskoe iskusstvo: Printsipy. Shkola. Mastera. Sostavlenie i perevod V.V. Maliavina [Chinese Art: Principles. School. Masters. Composed and translated by V.V. Maliavin]. (2004). Moscow, OAO Liuks, Astrel, AST, $432 \mathrm{p}$.

Kravtsova, M.E. (1999). Istoria kul'tury Kitaia. [The History of Chinese Culture]. St. Petersburg, Lan', 416 p.

Kravtsova, M.E. (2004). Mirovaia khudozhestvennaia kul'tura. Istoria iskusstva Kitaia: Uchebnoe posobie. [World Artistic Culture. The History of Chinese Art. Textbook]. St. Petersburg, Lan', TPKADA, 960 p.

Krivtsov, V.A. (1993). Estetitka daoisma. [Taoism Aesthetics]. Moscow, POO Fabula, 165 p.

Maliavin, V.V. (2000). Kitaiskaia tsivilizatsiia. [Chinese Civilization]. Moscow, AST, Dizain, Inform, Kartografiia, $627 \mathrm{p}$.

Maliavin, V.V. (2003). Sumerki Dao. Kul'tura Kitaia na poroge Novogo vremeni. [The Twilight of Tao. Chinese Culture on the Threshold of Modern Times]. Moscow, AST, Dizain, Inform, Kartografia, $436 \mathrm{p}$. 
Maslov, A.A. (2005). Tainy i smysli razgadka kodov Lao-tszy. [Secret Meaning and Key Codes of Lao Zi]. Rostov-na-Donu, Feniks, 288 p.

Ptitsa smerti. Perevod fragmenta [The Bird of Death. Translation of a Fragment], In Religii Kitaia.Khrestomatia. Sostavlenie E.A. Torchinova [Religions of China. Chrestomathy. Composed by E.A. Torchinova]. (2001). St. Petersburg, Evraziia, 26-29.

Rowley, G. (2004). Printsipy kitaiskoi zhivopisi [The Principles of Chinese Painting], In Kitaiskoe iskusstvo: Printsipy. Shkoly. Mastera. Perevod s angliiskogo V.V. Maliavina [Chinese Art: Principles. Schools. Masters. Translated from English by V.V. Maliavin]. Moscow, AST, 78-244.

Schipper, K. (1982). The Taoist Body, Physical Body - Social Body. Collection of Interior Space 25 [Le corps taoiste, corps physique corps social.Collection «L'espaceinterieur» 25]. Paris, Artheme Fayard, $344 \mathrm{p}$.

Sun Cho. Iui Tan'Taishan'Fu. Perevod fragmenta [Sun Cho.Yu Tan TaishanFu. Translation of a Fragment], In Religii Kitaia. Khrestomatia. Sostavlenie E.A. Torchinova [Religions of China. Chrestomathy. Composed by E.A. Torchinova]. (2001). St. Petersburg, Evraziia, 89-96.

Tkachenko, G.A. (2008). Chelovekipriroda v «Liushichun'tsiu» [Man and Nature in Lu Shi ChunQiu], In Tkachenko G.A. Izbrannyetrudy. Kitaiskaia kosmologiia i antropologia [Selected Works by G.A. Tkachenko. Chinese Cosmology and Anthropology]. Moscow, RAO Govoriashchaiakniga, 120-132.

Tkachenko, G.A. (2008). Otrazhenie traditsionnykh predstavlenii o kosmose v kitaiskom tekste III veka do nashei ery [Reflecting the traditional concepts of space in the Chinese text of the III century $\mathrm{BC}$ ], In Tkachenko G.A. Izbrannye trudy. Kitaiskaia kosmologi i aiantropologia [Selected Works by G.A. Tkachenko. Chinese Cosmology and Anthropology]. Moscow, RAO Govoriashchaiakniga, 101-119.

Vasil'ev, L.S. (1970). Cul'ty, religii, traditsii v Kitae. [Cults, Religions, Traditions in China]. Moscow, Nauka, 844 p.

Zavadskaia, E.V. (1978). «Besedy o zhivopisi» Shi-Tao [Talks about Painting by Shi Tao]. Moscow, Nauka, 208 p.

Zavadskaia, E.V. (1975). Esteticheskie problemy zhivopisi starogo Kitaia [Aesthetic Problems of the Old Chinese Painting]. Moscow, Iskusstvo, 439 p.

Zavadskaia, E.V. (1970). Vostokna Zapade [The East in the West]. Moscow, Nauka, 127 p.

\section{Традиции даосизма}

\section{в художественной культуре Китая}

А.А. Алепко

Хабаровский государственный институт культуры Россия, 680045, Хабаровск, ул. Краснореченская, 112

В предлагаемой статье автор рассматривает влияние даосизма на художественную культуру Китая, в частности, на национальную живопись. Предметом исследования является интерпретаџия образов китайской живописи даосской культурной традиџией. 
Изучение подтвердило, что в соответствии с даосской традицией китайский художнк смотрел на жизнь через призму искусства, никогда не писал с натуры и никогда не делал этюдов, как это принято в европейской живописи. Китайский художник, прежде чем писать свои картины, как натуралист тщательно и кропотливо изучал природу во всех ее мельчайших формах.

В своих работах китайские художники всегда руководствовались идеей динамического единства противоположностей, которые дополняют друг друга и, таким образом, нуждаются друг в друге. Художник не был классицистом или романтиком, он был и то и другое. Картины не были ни натуралистическими, ни идеалистическими, они объединяли эти качества. Стиль китайских художников предполагал сочетание общего и индивидуального. Это был тот способ, благодаря которому китайские художники находили «внутреннюю реальность» в своих картинах.

Ключевые слова: даосизм, живопись, символ, художник, пейзаж, каллиграфия.

Научная специальность: 24.00.00 - культурология. 